\title{
POLITICAL BENEFITS, BARRIERS, AND RISKS OF E-HRM IMPLEMENTATIONS IN BANGLADESH PUBLIC SECTOR ORGANISATIONS: AN INSTITUTIONAL PERSPECTIVE ${ }^{1}$
}

Mushfiqur RAHMAN ${ }^{2}$

Erhan AYDIN ${ }^{3}$

\author{
Received Date (Başvuru Tarihi): 01/11/2018 \\ Accepted Date (Kabul Tarihi): 15/11/2018 \\ Published Date (Yayın Tarihi): 30/11/2018
}

\begin{abstract}
This research aims at exploring a political perspective that includes political benefits, barriers and risks to E-HRM implementation in the context of Bangladesh through adopting an institutional perspective. In order to achieve this aim, we conducted 30 semi-structured qualitative interviews (15 in each ministry) in the Ministry of Foreign Affairs and Public Administration. Based on the interviews, the findings were thematised as three categories: political benefits, political barriers, and political risks. This research makes a robust contribution to the field as indicating different aspects of political perspectives by adopting an evidence-based approach that comes from the qualitative orientation of this research. This also provides a map for understanding current political benefits, barriers and risks regarding e-HRM implementation.
\end{abstract}

Keywords: Politics, e-HRM, HRM, Institutional Perspective, e-HRM Implementation, Bangladesh

Jel Codes: $M 1, M 0, I 5$

\section{BANGLADEŞ KAMU SEKTÖR ÖRGÜTLERINDE E-IKY UYGULAMALARININ POLITIK FAYDALARI, ENGELLERI VE RISKLERI: KURUMSAL BIR YAKLAŞIM}

ÖZ

Bu araştırma, kurumsal perspektifi benimseyerek Bangladeş bağlamında E-İKY (İnsan Kaynakları Yönetimi) uygulamasına yönelik politik faydaları, engelleri ve riskleri içeren politik bir bakış açısını keşfetmeyi amaçlamaktadır. Bu amaca ulaşmak için Dışişleri ve Kamu Yönetimi Bakanlığı'nda 30 yarı yapılandırılmış nitel görüşmeler (her bakanlıkta 15 olmak üzere) gerçekleştirilmiştir. Görüşmelere göre, bulgular politik faydalar, politik engeller ve politik riskler olmak üzere üç kategori altında temalandırılmıştır. Bu araştırma, nitel yaklaşımın doğasından gelen kanıt-tabanlı yaklaşımı benimsemekte ve politik bakış açılarını göstererek alana katkı sağlamaktadır. Bu aynı zamanda, e-HRM uygulamasına ilişkin mevcut politik faydaları, engelleri ve riskleri anlamak için bir harita da sunmaktadır.

Anahtar Sözcükler: Politika, e-IKKY, IKY, Kurumsal Perspektif, e-İKY Uygulamalarl, Bangladeş

Jel Kodlart: $M 1$, MO, I5

\footnotetext{
${ }^{1}$ This paper is the final version of the work which has been significantly improved and extended after being presented at the International Business and Organization Research (BOR) Conference in Safranbolu between 12 -14 September 2018.

${ }^{2}$ Brunel University London, mushfiqur.rahman@brunel.ac.uk

${ }^{3}$ Usak University, Turkey, e.aydin@ipag.fr 


\section{INTRODUCTION}

Organisations in their environmental settings are often affected by external forces such as decision makers and political instability (Bondarouka and Heijden, 2009). To respond these forces, HR managers develop their internal organisational structure and behaviours flexible enough. The main reason of these practices comes from dealing with the external forces (Bell et al., 2006). Some research (e.g. Bondarouka et al., 2009), on the other hand, demonstrates that political systems in which power games and political influence over decision- making have an impact to describe internal processes. Due to the fact that organisational politics is a unique domain of interpersonal relation in the workplace (Vigoda and Cohen, 2003, Bacharach, 2005), it creates a political influence that provides transforming HR system to E- HRM (Electronic- Human Resource Management) for various reasons.

A political influence occurs through budget allocation, conflicts between top management and functional level employees, fearing to lose the job by employees, and political leaders (Lengnick-Hall et al., 2003; Vigoda and Drory, 2006). These are three scenarios that government may adopt. In this research, we demonstrate how these scenes are perceived by employees and how employees understand political perspective to e-HRM implementations in their public sector organisations. To answer these research questions, this paper has been organised in three sections. In the first section, we provide a theoretical framework regarding political perspective in e-HRM implementations in order to emphasise primary dimensions in the political context of e-HRM that comes from the literature. In the second section, we introduce the research method of this study. In the third section, we demonstrate our findings based on the frames that we discuss in the first section, and lastly, we conclude our research with discussing political perspective to e-HRM implementation in public sector organisations in the context of Bangladesh where we conduct the semi- structured interviews.

\section{THEORETICAL FRAMEWORK}

Institutions comprise informal constraints such as sanctions, taboos, traditions and codes of conduct, and formal rules, which come from regulations and legislations. The main reason for creating institutions is to provide order and remove any concerns and uncertainty in society (North, 1991). For this reason, there are three institutional settings. The first one is formal institutions, which have their power from constitutions, policies, laws and legal agreements. The second one is informal institutions, which have their power from behavioural norms and mental models of individuals. Mental models consist of various fields such as religious and political beliefs. The third one is organisations, which shape collective interests as codifying formal rules, informal practices or both (Doh and Guay, 2006). In our research context, public sector organisations have these three institutional settings because the structure of organisations comes from laws and regulations since they are Ministry of Foreign Affairs 
(MOFA) and Ministry of Public Administration (MOPA). On the other hand, political thoughts and ruling party form the structure of these organisations through considering formal rules and informal practices that stem from political intervention to hire employees or employees' behaviour in the organisations.

Institutions are a critical component of the social environment which shape organisational structures, the orders of social relationships and sovereignty, which indicate who has power and gets access to beneficial resources (DiMaggio and Powel, 1983; Fligstein 2001; Yang and Konrad, 2011). In this regard, the power of these institutional structures comes from self-reinforcement through reproducing power positions and eliciting dominant elites to protect these structures for creating a continual position of authority (Greenwood and Hinings, 1996). For this reason, public sector organisations as one of the institutional settings demonstrate a political-social environment that shapes organisational structure based on the ruling party. Such an environment also provides the orders of social relationships amongst employees with accepting power of ruling party that is called as sovereignty in institutional perspective (Tolbert and Zucker, 1999; Doh and Guay, 2006; Scott and Meyer, 1983: 149; Kondra and Hinings, 1998; Martinez and Dacin, 1999; Lawrence and Suddaby, 2006; Meyer and Rowan, 1977; Bjorkman et al., 2007).

Suddaby (2010) states that the institutional perspective includes cultural persistence in organisations that introduce three concepts: "generational uniformity of cultural understanding, maintenance of these understandings, and resistance of these understandings to change" (Zucker, 1977: 726). For instance, change process from HRM to e- HRM systems creates an organisational climate that employees have resistance to change because of various reasons such as lack of expertise regarding technology. Accordingly, the institutional theory aims for understanding how the decisions and behaviours of organisations and individuals are shaped by the institutional environments in which this decision and behaviours are embedded (Dacin et al., 1999; Meyer and Rowan, 1983; Battilana and D' Aunno, 2011; Hodgson, 2000).

The institutional theory helps us to understand e- HRM implementation in political settings because the theory gives the general structure about implementing e- HRM in public sector organisations. In order to create an initial theoretical framework for our research, we discuss politics in e-HRM implementation in the next section. Following the discussion, we introduce our research method.

\subsection{Understanding Political Perspective in e-HRM Implementations}

Political perspective has been conceptualised as one of the external forces which cover government decisions on public sector organisations (Ball, 2001; Smale and Heikkilä, 2009), and the decisions have a significant role in adopting new technologies for HRM; because government 
considers challenges of transforming their existing HRM to e-HRM systems (Wright and Dyer, 2000). The political leaders, for this reason, need to consider obstacles concerning budget from the government, the influence of labour union and organisational capability to change existing HRM to eHRM systems in the context of developing countries such as Bangladesh (Absar et al., 2012).

Governments which are one of the stakeholders are responsible for facilitating the implementation of e-HRM in different ministries that have been considered as public sector organisations (Marler and Fisher, 2013). The stakeholders play a crucial role in effective implementation of e-HRM since organisations depend largely on political leaders (Burbach and Royle, 2014), and policy and strategic decision-makers for the provision of adequate budget (Bissola and Imperatori, 2014) to support the government project financially and desire that leads to implementation success (Gil-Garcia et al., 2009; Schwester, 2009). The government, for this reason, needs to keep financial support and invest in Information and Communication Technologies (ICT). In the parallel of this knowledge, we adopt political perspective as discussing its benefits, barriers and risks since the government is responsible for the success of e-HRM implementations.

\subsection{Benefits in Political Perspective}

A government that is amongst the stakeholders of a state must adopt a political strategy which aims at reducing expenditures of an investment and diagnosing potential benefits. For this reason, a government considers benefits of a political perspective to gain efficient results in e-HRM implementations. In this respect, our research focuses firstly on how a government decides to be able to have beneficial results for their decision (Jaradat, 2013) and also the literature emphasises the benefits as strong financial supports (Ruel et al., 2004), and legislations and regulations (Reddick, 2009; Martin and Reddington, 2010) that we explain as follows:

Financial Support: The government funds bear all of the expenses for different ministries; therefore, the decision makers do not need to think about the costs for new facilities or systems (Schwester, 2009). Also, once a new system has been implemented in the HR department in an organisation, the government bear the relevant costs; for example, employee training, maintenance and hiring adequate experts (Strohmeier, 2007).

Legalisation and the Necessary Regulation: The legalisation and the regulation are essential to organise the e-HRM system process by giving the every employee a particular privilege (Gil-Garcia et al., 2009), as well as, the regulation is crucial to ensure the privacy and the security of the information on the system (Schwester, 2009).

\subsection{Barriers in Political Perspective}

In addition to political benefits, another issue that a government must consider is related to the types of barriers that they face during the changing process from HRM to e-HRM. However, as a 
result of political inconsistencies in developing countries, the government can change and ignore the implementations of previous government; thus this has an impact on the maintaining costs of the eHRM system due to the fact that the system is based on technology which contentiously needs to upgrade or update. On the other hand, the literature raises power game change (Bondarouka and Ruel, 2009), and decision maker's decision (Reddick, 2009; Beulen, 2009) amongst the political barriers in a generic way. We examine these two perspectives as follows:

Power Game Change: As emphasised by scholarly literature, the political systems where power games and political influence over decision-making are useful for the sake of describing the landscape of internal process (Beulen, 2009). Moreover, the power change may result in failure of the system if the power game clash together (Bondarouka and Heijden, 2009).

Decision-Making: The decision maker is crucial in the process of implementing e-HRM (Parry, 2011) as they control the HRM policy, employee benefit and reward system (Strohmeier, 2009). The employees will not be happy if the decisions are unfair and it may impact on the expected performance of e-HRM (Reddick, 2009). After that, the decision maker regarding reward system should be fair, if personal feelings interfere with the promotion or the reward, it could cause a huge problem in implementing e-HRM (Beulen, 2009).

\subsection{Risks in Political Perspective}

Political risks are the future uncertainty that can impact seriously in the process of implementation of e-HRM (Smale and Heikkilä, 2009). A public organisation may face different challenges in implementing the decision made by the previous government. For example, if the previous government decided to implement e-HRM in an organisation, the new government may not be willing to continue. As a result of the inconsistent decisions that come from government changes, the efficiency of the whole systems will be affected in a negative way. On the other hand, the scholarly literature points out major risks that are: Employees Resistance (Jaradat, 2013), Political Instability (Smale and Heikkilä, 2009), Annual Budget Decreased (Haines and Petit, 1997).

Resistance to Change: Resistance to change is another major barrier in developing countries such as Bangladesh where most of the public organisations are based on paper based traditional administrative system (Jaradat, 2013). The other relevant ministries may not be able to adapt with and accept the e-HRM (Strohmeier, 2009). Therefore, resistance to change could be a barrier to implementing the e-HRM system in the organisations.

Political Instability: The Political instability is one of the main risks for every organisation. The new government may not be willing to continue with the previous government's policy and strategy; that may affect the performance and effectiveness of systems in public organisations (Smale and Heikkilä, 2009). 
Annual Budget Decreased: The annual budget for may be reduced because of the government decision and e-HRM implementation will be affected (Parry ad Wilson, 2011). Industrial action or strike by employee union are another major political risk that may affect the effectiveness of e-HRM implementation as all employees' participation is needed to get the result from a system based on technology (Haines and Petit, 1997).

Based on the institutional approach and political perspective that we discussed in aforementioned sections, Figure 1 demonstrates our initial theoretical framework regarding e- HRM implementation in public sector organisations.

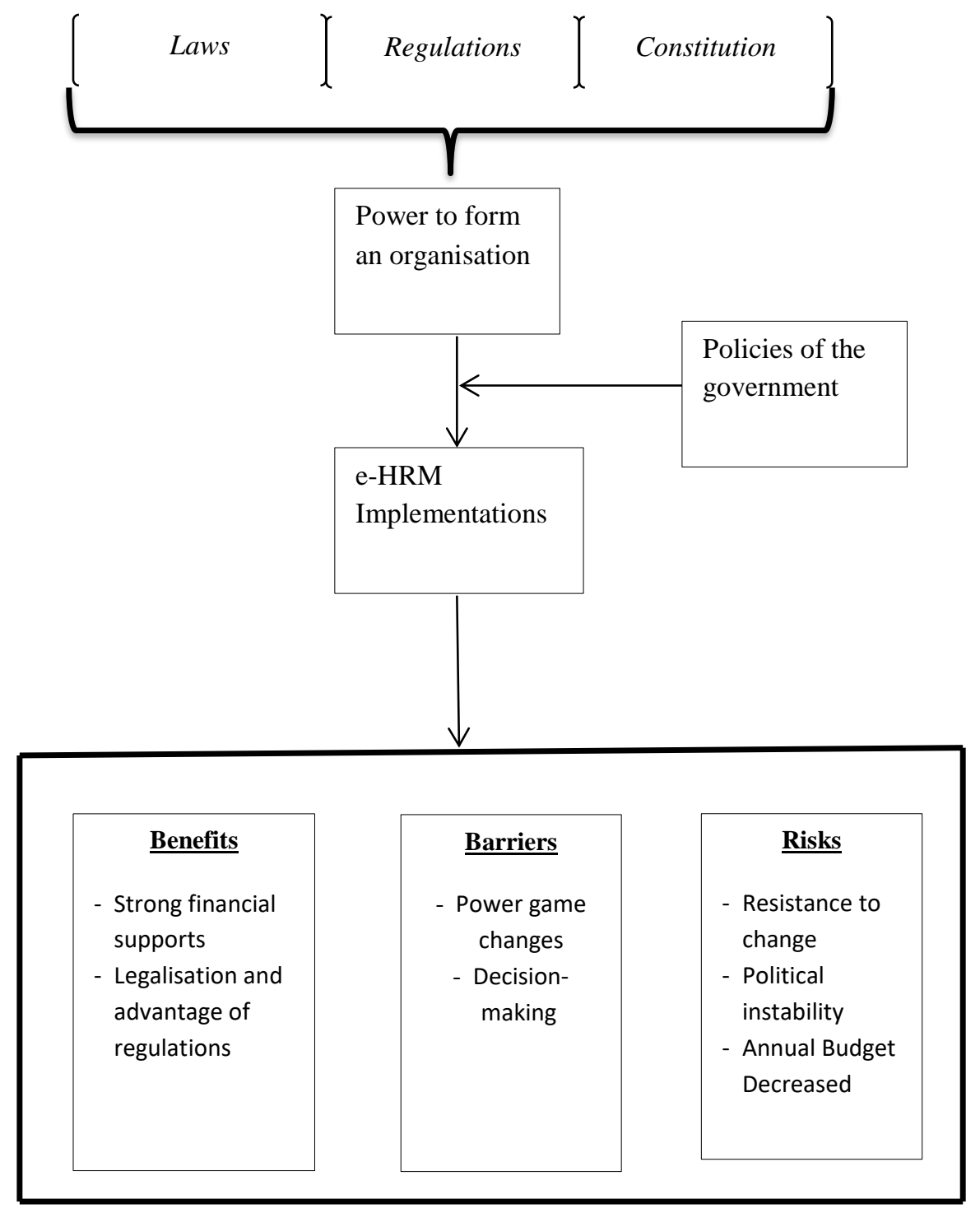

Figure 1. Initial Theoretical Framework: Institutional Approach to E- HRM Implementations In Politics

Following the initial theoretical framework, we now turn to introduce research method in the next section. 


\section{RESEARCH METHOD}

This research aims at having a nature to focus on flexibility and specificity instead of creating a standardised and generalised perspective. For this reason, we provide this nature through qualitative orientation (Marshall and Rossman, 2006). The empirical part of this study comes from semistructured qualitative interviews. Based on the snowball sampling, the first author of this research conducted 30 semi- structured interviews (15 in Ministry of Foreign Affairs and 15 in Ministry of Public Administration) in the context of Bangladesh. The method that we adopt is called as a qualitative case study that provides rich and naturalistic data (Stake, 1995). The main feature of such a study is to consider same questions for different organisations and to conclude them after comparing with each other (Ghauri and Gronhaug, 2005).

Ministry of Foreign Affairs and Ministry of Public Administration were chosen as the cases for analysis of providing a political perspective to e-HRM; because whilst Ministry of Foreign Affairs provides a link between Bangladesh and other countries, the Ministry of Public Administration provide a link between the government and the citizens. For this reason, the ministries are crucial amongst others.

We employed thematic analysis for the data that comes from semi- structured qualitative interviews. Also, NVivo 10, a computer- assisted qualitative data analysis package, was used for the analysis (Soylu and Sheehy- Skeffington, 2015). In order to have a meaningful and manageable segment for the data, we applied preliminary codes to the textual data. Thus, we were able to reach the core concepts that embrace the most important points in the text (Attride- Stirling, 2001; Miles and Huberman, 1994; Braun and Clarke, 2006).

The interviewees of this research are demonstrated in Table 1 through indicating their organisations, positions and their length of services. 
Table 1: Participants Of This Research

\begin{tabular}{|c|c|c|c|c|c|}
\hline $\begin{array}{l}\text { Code } \\
\text { No. }\end{array}$ & Organisation MOFA & $\begin{array}{l}\text { Length of } \\
\text { Service }\end{array}$ & $\begin{array}{l}\text { Code } \\
\text { No. }\end{array}$ & Organisation MOPA & Length of Service \\
\hline 1 & $\begin{array}{c}\text { Director of Senior } \\
\text { Management Operation } \\
\text { (SMO) }\end{array}$ & 21 and over & 2 & $\begin{array}{c}\text { Director of Operation } \\
\text { Management }\end{array}$ & 21 years and over \\
\hline 3 & $\begin{array}{c}\text { Secretary (Chief Training } \\
\text { \&Consular) }\end{array}$ & $16-20$ & 4 & Assistant General Manager & $16-20$ years \\
\hline 5 & $\begin{array}{c}\text { Personnel Director P\&O \& } \\
\text { ICT }\end{array}$ & 21 years and over & 6 & Deputy General Manager & 21 years and over \\
\hline 7 & $\begin{array}{c}\text { Director General (Admin \& } \\
\text { ICT) }\end{array}$ & 21 and over & 8 & Head of IT & 21 years and over \\
\hline 9 & Deputy Director (Finance) & 21 and over & 10 & $\begin{array}{c}\text { Assistant Head of HR and } \\
\text { Administration }\end{array}$ & 21 years and over \\
\hline 11 & Director General (Research) & 21 and over & 12 & $\begin{array}{c}\text { Deputy Head of HR and } \\
\text { Administration }\end{array}$ & 21 years and over \\
\hline 13 & IT Manager & $16-20$ years & 14 & $\begin{array}{c}\text { Training and Recruitment } \\
\text { Manager }\end{array}$ & $16-20$ years \\
\hline 15 & HR Manager & $16-20$ years & 16 & HR Manager & $16-20$ years \\
\hline 17 & HR Supervisor (Field Staff) & 11-15 years & 18 & HR Supervisor (Field Staff) & 11-15 years \\
\hline 19 & HR Supervisor (Home Staff) & $11-15$ years & 20 & $\begin{array}{c}\text { HR Supervisor (Home } \\
\text { Staff) }\end{array}$ & $11-15$ years \\
\hline 21 & Line manager Procurement & 11-15 years & 22 & Line manager Procurement & $11-15$ years \\
\hline 23 & HR office assistant & $6-10$ years & 24 & HR office assistant & $6-10$ years \\
\hline 25 & Finance Officer & $1-5$ years & 26 & Finance Officer & $1-5$ years \\
\hline 27 & PA HR director & $1-5$ years & 28 & PA HR director & $1-5$ years \\
\hline 29 & HR Officer & 6-10 years & 30 & HR Officer & $6-10$ years \\
\hline
\end{tabular}

As it is seen in Table 1, participants of this research have similar positions in two different organisations and also they have a similar length of service. In the following section, we demonstrate findings based on the interview analysis.

\section{FINDINGS AND DISCUSSION}

Based on the 30 interviews that were conducted by the first author of this paper, we divide findings into three sections as political benefits, political barriers and political risks. In order to create a detailed analysis regarding political perspective to e- HRM implementation in Bangladesh, we extend generic literature through providing specific concepts for each pillar of political point of view. 


\subsection{Political Benefits: First Pillar}

The findings of this research demonstrate that two cases have a different perspective on political benefits. Whilst MOFA focuses on the positive political image; MOPA considers efficient knowledge transfer in the context of Bangladesh. A participant from MOFA indicates the importance of political image as follows:

The introduction of e-HRM has improved our political image abroad. The ministry of foreign affairs is one of the most benefited from the implementation of e-HRM because it has become very easy to refer foreign government that needs information about our policy to the online materials. Moreover, the implementation of e-HRM meant that foreigners could access information about business and visa procedure online. (Participant 11).

Strachan and Kendall (2004: p.135) describe the political image as referring to "a carefully constructed consideration of all the attributes that a candidate wants to convey to the voters easily recalled, visual and verbal symbols". Schill (2012) also encourage the same perspective regarding the political image. The findings of this research, however, demonstrate that political image of the government is also necessary for communicating with other countries. For this reason, successful implementation of e- HRM in Bangladesh creates a positive political image in the international area for the government.

MOPA, on the other hand, considers the public side of political benefits as the emphasising efficiency of knowledge transfer, because e-HRM provides easy access to updated information such as legislations and regulations. An interviewee from MOPA states this perspective as follows:

One of the most important issue in implementing e-HRM is to provide knowledge dissemination. The Government has to publish the related information of changes in the newspaper and e-media. Also, this situation creates both political and financial benefits in terms of getting more support from the citisens. (Participant 10).

E- HRM systems provide remote access to HR information where employees and managers need to reach (Parry and Tyson, 2011). On the other hand, the system protects the data that stored on computerised systems because "it is often confidential and private, and should be accessible only to approved individuals under controlled conditions" (Kovach and Catchcart, 1999: p. 280). These benefits make e- HRM systems attractive for state people who decide to implement the system in the organisations. 
Even though the participants raised the importance of positive political image and efficient knowledge transfer, the participants are also aware of the barriers of e- HRM implementation. For this reason, we demonstrate the political barriers based on the findings in the following section.

\subsection{Political Barriers: Second Pillar}

The findings of this research show three barriers for e- HRM implementations in Bangladesh that are inconsistent policies, attempting to sabotage, and political influences. The barriers have a great importance on e-HRM implementations because the government that does not consider the barriers can face a failed implementation of e- HRM in the organisations.

The findings demonstrate one of the most crucial barriers is inconsistent policies. For instance, a member of MOFA states this barrier as follow:

Politicians have a tendency to renew every system and to create new projects instead of following previous ones. For this reason, such situations cause policies that are constantly changed. This is a critical barrier for implementing e-HRM system. (Participant 9).

MOFA focuses on international relations of a state. For this reason, inconsistent policies are examined an important political barrier. Another reason that participants raise this barrier comes from being a developing country that has changing policies in all government implementations because there are no standard policies for the country which a new government wants to adopt. On the other hand, Bangladesh, specifically, "became an independent state in 1971 after a bloody liberation war with Pakistan" (Bhuiyan, 2011: 55). For this reason, it is a young country that does not have consistent policies in governing the state. Thus, different political parties adopt different policies when they come into power. The interviewes demonstrate whilst MOFA raises inconsistent policies; MOPA considers political influence as one of the barriers. An interviewee examines this barrier as follows:

The government policies affect implementation of e-HRM. However, there can be conflicts between previous and current government policies. This is an important barrier for the success of implementing e-HRM. (Participant 16).

Participant 16 emphasises political influence on e-HRM implementations in the interview. The findings show that the main reason for this claim comes from competition amongst political parties. If another political party comes to the power, it can change implementations of the previous government. This situation also creates another barrier for eHRM implementation. A participant examines the situation as follows: 
In this country, most people have an allegiance or affiliation with a particular political party. This means that they hold the strong political view. So whenever, a party that they do not support is in power, they have a tendency to be disloyal and destructive. This means that they can do anything to frustrate the plan of the new government. (Participant 19).

This participant raises the issue of an attempting to sabotage for a political barrier that has an adverse impact on the employees in the organisation. This situation is called as organisational deviance in the literature that creates a severe damage for organisations (Bennett and Robinson, 2000; Robinson and Benett, 1995). The concept is defined as "voluntary behaviour that violates organisational norms and thereby threatens the well-being of the organisation, its members, or both" (Gils et al., 2015: 190). In addition to organisational challenges because of the political barriers, the findings indicate political risks that also can create the barriers.

\subsection{Political Risks: Third Pillar}

Implementing an e-HRM system in developing countries may raise many political issues; first, the political instability is one of the main risks for every organisation (Smale and Heikkilä, 2009). New governments may not be willing to continue with the previous government's policy and strategy (Bondarouk, 2011), that may affect the performance and effectiveness of systems in public organisations. This issue is called as conflicts amongst different political parties and insufficient decision-making processes. The participant 3 and the participant 4 state these risks as follows:

It is very risky to implement e-HRM as there was no cooperation between the government and the opposition party on the programme. (Participant 3).

The opposition party has constantly opposed the implementation of e-HRM; therefore it is likely that when they get into power, they will stop the programme. (Participant 21).

The aforementioned situations require change programs in organisations. However, the findings demonstrate that the employees in public sector organisations (MOPA and MOFA in our research context) can resist to these changes which are a result of organisational deviance.

In this research, we point out the dimensions of political benefits, barriers and risks. Figure 2 states proposed theoretical framework for our research. 


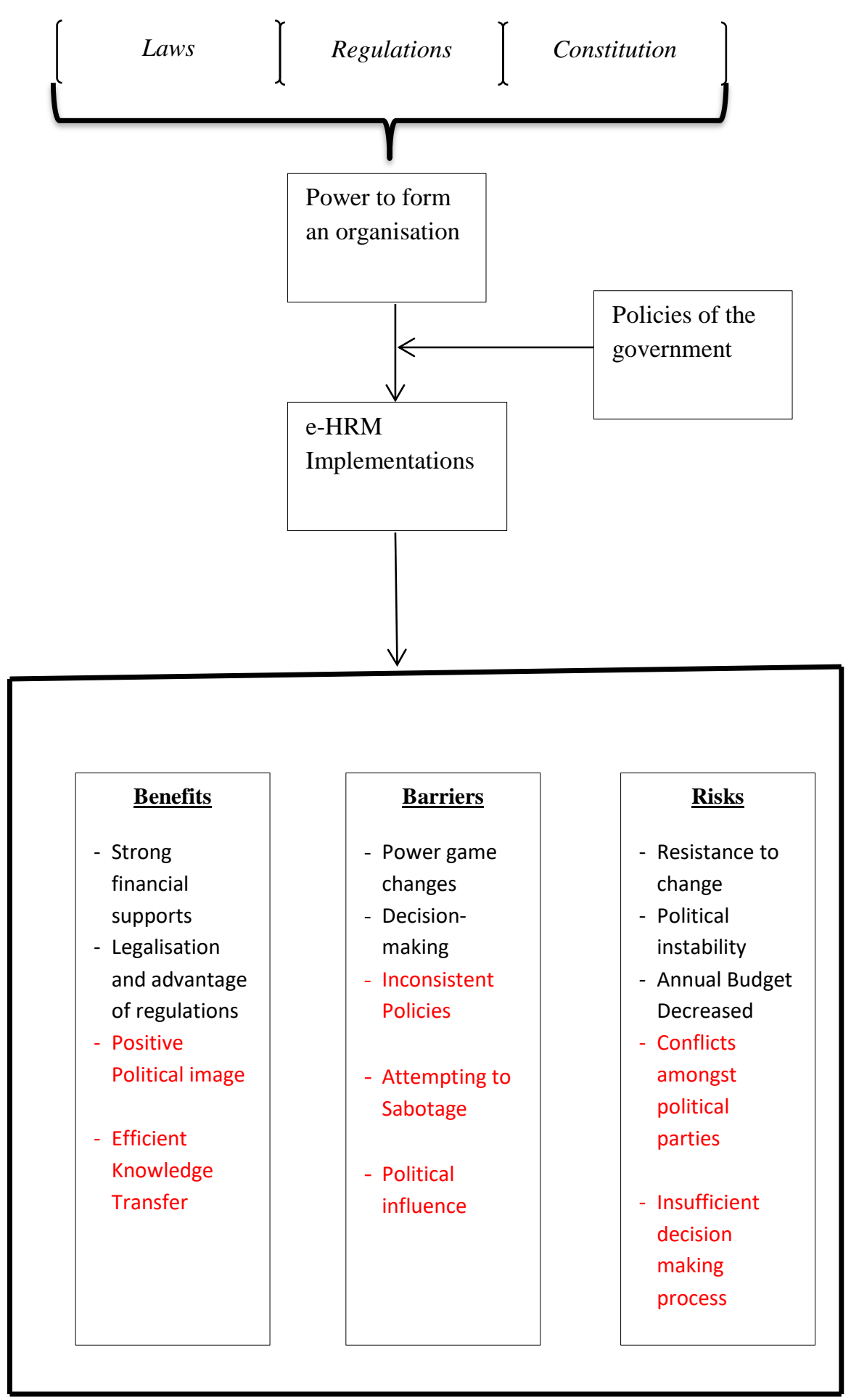

Figure 2. Proposed Theoretical Framework: Institutional Approach to E- HRM Implementations In Politics

\section{CONCLUSION}

This research aims at exploring political perspectives to e-HRM implementations in public sector organisations through adopting institutional theory. In order to achieve this aim, we conducted 30 semi- structured qualitative interviews in MOFA and MOPA. The findings demonstrate that 
political perspective includes benefits, barriers and risks in terms of understanding e-HRM implementation. However, as we stated in the literature section of this research, three political perspectives have been discussed in a generic way. For this reason, we explored which dimensions that should be included in the research to make more comprehensive analysis of political perspectives to public organisations. This also was the main contribution of this research to the e-HRM field. As we stated in Figure 2, knowledge transfer, political image, inconsistent policies, attempting to sabotage, conflicts amongst political parties, resistance to change, and insufficient decision-making process are the issues the politicians should focus on in the context of developing countries. Such a perspective can provide standardised programs for adoption and improvement of e-HRM implementations in the public sector organisations.

Institutional theory, on the other hand, was adopted in this research. The main reason for using the perspective stems from creating an institutional setting for our context. For instance, based on the e-HRM literature, the initial theoretical framework (Figure 1) showed that how e- HRM implementations were institutionalised through the process of forming the public sector organisations. This framework was developed after the analysis of the findings. Thus, we were able to make an immense contribution to the e- HRM literature that omits the dimensions that we discussed in the findings. 


\section{REFERENCES}

Absar, N., Nimalathasan, B. and Mahmood, M. (2012). 'HRM-market performance relationship: evidence from Bangladeshi organizations', South Asian Journal of Global Business Research, 1(2), pp. 238-255.

Attride-Stirling, J. (2001). Thematic networks: an analytic tool for qualitative research. Qualitative research, 1(3), 385-405.

Ball, K. (2001). 'The use of human resource information systems: A survey', Personnel Review, 30(6), pp. 677-693.

Battilana, J. and D'aunno, T. (2011) 'Institutional work and the paradox of embedded agency', in LAwrence, T., Suddaby, R. and Leca, B. (eds.) Institutional Work: Actors and Agency in Institutional Studies of Organizations. 2nd edn. Cambridge: Cambridge University Press, pp. 31-58.

Bell, B., Lee, S. and Yeung, S. (2006) 'The Impact of e-HR on Professional Competence in HRM: Implications for the Development of HR Professionals', Human Resource Management, 45(3), pp. 295-308.

Bennett, R. J., \& Robinson, S. L. (2000). Development of a measure of workplace deviance. Journal of Applied Psychology, 85(3), 349360

Beulen, E. (2009). 'The Enabling Role of Information Technology in the Global War for Talent: Accenture's Industrialized Approach', Information Technology for Development, 14(3), pp. 213-224

Bhuiyan, S. H. (2011). Modernizing Bangladesh public administration through e-governance: Benefits and challenges. Government Information Quarterly, 28(1), 54-65.

Bissola, R. and Imperatori, B. (2014) 'The Unexpected Side of Relational e-HRM', Employee Relations, 36(4), pp. $376-397$.

Björkman, I., Fey, C. F., \& Park, H. J. (2007). Institutional theory and MNC subsidiary HRM practices: Evidence from a three-country study. Journal of International Business Studies, 38(3), 430-446.

Bondarouk, T. (2011). 'Theoretical approaches to e-HRM implementations', Electronic HRM in Theory and Practice, pp. 1-20.

Bondarouk, T. and Ruël, H. (2009). 'Electronic Human Resources management: Challenges in the Digital Era', International Journal of Human Resources Management, 20(3), pp. 503-514.

Bondarouk, T. and Ruël, H. (2009). 'Electronic Human Resources management: Challenges in the Digital Era', International Journal of Human Resources Management, 20(3), pp. 503-514.

Bondarouk, T.V., Ruël, H. and van der Heijden, B. (2009). 'e-HRM Effectiveness in a Public Sector Organization: A Multi-Stakeholder Perspective', International Journal of Human Resource Management, 20(3), pp. 578-590.

Braun, V., \& Clarke, V. (2006). Using thematic analysis in psychology. Qualitative research in psychology, 3(2), 77-101.

Burbach, R., \& Royle, T. (2014). Institutional determinants of e-HRM diffusion success. Employee Relations, 36(4), 354-375.

Dacin, M.T., Ventresca, M.J. and Beal, B.D. (1999) 'The embeddedness of organizations: Dialogue \& directions', Journal of management, 25(3), pp. 317-356.

DiMaggio, P. and Powell, W.W. (1983) 'The iron cage revisited: Collective rationality and institutional isomorphism in organizational fields', American Sociological Review, 48(2), pp. 147-160.

Doh, J.P. and Guay, T.R. (2006) 'Corporate social responsibility, public policy, and NGO activism in Europe and the United States: an institutional-stakeholder perspective', Journal of Management Studies, 43(1), pp. 47-73.

Fligstein, N. (2001) The architecture of markets: An economic sociology of twenty-first-century capitalist societies. Princeton: Princeton University Press.

Ghauri, P.N. and Gronhaug, K. (2005), Research Methods in Business Studies: A Practical Guide, 3rd ed., FT-Prentice Hall, London.

Gill, J. and Johnson, P. (2002). Research Methods for Managers, London: Sage Publications.

Gils, S., Quaquebeke, N., Knippenberg, D., Dijke, M., \& De Cremer, D. (2015). Ethical leadership and follower organizational deviance: The moderating role of follower moral attentiveness. The Leadership Quarterly, 26(2), 190-203.

Gottschalk, P. (1999). 'Implementation Predictors of Strategic Information Systems Plans', Information and Management, 36(2), pp. 77-91.

Greenwood, R. and Hinings, C.R. (1996) 'Understanding radical organizational change: Bringing together the old and the new institutionalism', Academy of management review, 21(4), pp. 1022-1054.

Haines, V.Y. and Petit, A. (1997). 'Conditions for Successful Human Resource Information Systems', Human Resource Management, 36(2), pp. 261-275.

Hodgson, G.M. (2000) 'What is the essence of institutional economics?', Journal of economic issues, 34(2), pp. 317-329.

Jaradat, N. (2013). 'Electronic Human Resource Management: Issues and Challenges in Jordanian Universities', Interdisciplinary Journal of Contemporary Research in Business, 4(12), pp. 685-710.

Kondra, A.Z. and Hinings, C.R. (1998) 'Organizational diversity and change in institutional theory', Organization Studies, 19(5), pp. 743-767.

Kovach, K. A., \& Cathcart, C. E. (1999). Human resource information systems (HRIS): Providing business with rapid data access, information exchange and strategic advantage. Public Personnel Management, 28(2), 275-282.

Lawrence, T.B. and Suddaby, R. (2006) 'Institutions and institutional work', in Clegg, S., Hardy, C., Lawrence, T. and Nord, W. (eds.) The Sage Handbook of Organization Studies. 2nd edn. London: Sage, pp. 215-254.

Lengnick-Hall, M. L. and Moritz, S. (2003). 'The Impact of e-HR on the Human Resource Management Function', Journal of Labour Research, 24(3), pp. 365-379.

Lichbach, M. I. (2005). Information, trust, and power: the impact of conflict histories, policy regimes, and political institutions on terrorism. International Studies Review, 7(1), 162-165.

Marler, J.H. and Fisher, S.L. (2013). 'An Evidence-based Review of e-HRM and Strategic Human Resource Management', Human Resource Management Review, 23(1), pp. 18-36.

Marshall, C. and Rossman, G.B. (2006), Designing Qualitative Research , 4th ed., Sage, Thousand Oaks, CA

Martin, G. and Reddington, M. (2010). 'Theorizing the links between e-HR and strategic HRM: a model, case illustration and reflections', The International Journal of Human Resource Management, 21(10), pp. 1553-1574. 
Martinez, R.J. and Dacin, M.T. (1999) 'Efficiency motives and normative forces: Combining transactions costs and institutional logic', Journal of Management, 25(1), pp. 75-96.

Meyer, J. W., \& Rowan, B. (1983). The structure of educational organizations. In J. W. Meyer \& W. R. Scott (Eds.), Organizational environments: Ritual and rationality (pp. 71-97). Beverley Hills, CA: Sage

Meyer, J.W. and Rowan, B. (1977) 'Institutionalized organizations: Formal structure as myth and ceremony', American journal of sociology, , pp. 340-363.

Miles, M. B., \& Huberman, A. M. (1994). Qualitative data analysis: An expanded sourcebook. Sage.

North, D.C. (1991) Institutions, institutional change and economic performance. Cambridge university press.

Parry, E. and Wilson, H. (2011). 'Factors Influencing the Adoption of Online Recruitment', Personnel Review, 38(6), pp. 655-673.

Parry, E., \& Tyson, S. (2011). Desired goals and actual outcomes of e-HRM. Human Resource Management Journal, 21(3), 335-354.

Reddick, C.G. (2009). 'Human Resources Information Systems in Texas City Governments: Scope and Perception of its Effectiveness', Public Personnel Management, 38(4), pp. 19-34.

Reddick, C.G. (2009). 'Human Resources Information Systems in Texas City Governments: Scope and Perception of its Effectiveness', Public Personnel Management, 38(4), pp. 19-34.

Robinson, S. L., \& Bennett, R. J. (1995). A typology of deviant workplace behaviors: A multidimensional scaling study. Academy of Management Journal, 38(2), 555-572.

Ruël, H., Bondarouk, T. and Looise, J.K. (2004). 'E-HRM: Innovation or Irritation. An Explorative Empirical Sudy in Five Large Companies on Web-based HRM', Management Revue, 15(3), pp. 364-381.

Schill, D. (2012). The visual image and the political image: A review of visual communication research in the field of political communication. Review of Communication, 12(2), 118-142.

Schwester, R. (2009). Examining the barriers to e-government adoption. Electronic Journal of e-government, 7(1), 113-122.

Scott, W.R. (2008) 'Approaching adulthood: the maturing of institutional theory', Theory and society, 37(5), pp. 427-442.

Scott, W.R. and Meyer, J.W. (1983) 'The organization of societal sectors', in Meyer, J.W. and Scott, W.R. (eds.) Organizational Environments: Ritual and Rationality. Beverly Hills, CA: Sage, pp. 129-153.

Smale, A. and Heikkilä, J.P. (2009). IT-Based integration of HRM in a foreign MNC subsidiary: A micro-political perspective. Handbook of Research on E-Transformation and Human Resources Management Technologies: Organizational Outcomes and Challenges, pp. 153-170.

Smale, A., \& Heikkilä, J. P. (2009). IT-based integration of HRM in a foreign MNC subsidiary: a micro-political perspective. Handbook of Research on E-Transformation and Human Resources Management Technologies: Organizational Outcomes and Challenges, 153-170.

Soylu, S., \& Sheehy-Skeffington, J. (2015). Asymmetric intergroup bullying: The enactment and maintenance of societal inequality at work. human relations, 0018726714552001.

Stake, R.E. (1995), The Art of Case Study Research , Sage, Thousand Oaks, Vol. 10 No. 3, pp. 85-91.

Strachan, J. C., \& Kendall, K. E. (2004). Political candidates' convention films: Finding the perfect image-An overview of political image making. In eds (Charles A. Hill and Margueritte Helmers) Defining visual rhetorics, 135- 154, Lawrence: London

Strohmeier, S. (2007). 'Research in e-HRM: Review and implications', Human Resource Management Review, 17(1), pp. 19-37.

Strohmeier, S. (2009). 'Concepts of e-HRM consequences: a categorisation, review and suggestion', The International Journal of Human Resource Management, 20(3), pp. 528-543.

Strohmeier, S. (2009). 'Concepts of E-HRM Consequences: A Categorisation, Review and Suggestion', The International Journal of Human Resource Management, 20(3), pp. 528-543.

Suddaby, R. (2010) 'Challenges for institutional theory', Journal of Management Inquiry, 19(1), pp. 14-20.

Tolbert, P.S. and Zucker, L.G. (1999) 'The institutionalization of institutional theory', Studying Organization.Theory \& Method.London, Thousand Oaks, New Delhi, , pp. 169-184.

Vigoda, E. and Cohen, A. (2003). 'Work Congruence and Excellence in Human Resource Management: Empirical Evidence from the Israeli non-profit Sector', Review of Public Personnel Administration, 23, pp. 192-216.

Vigoda-Gadot, E., \& Drory, A. (Eds.). (2006). Handbook of organizational politics. Edward Elgar Publishing.

Wright, P. M., \& Dyer, L. (2000). People in the e-business: new challenges, new solutions.

Yang, Y. and Konrad, A.M. (2011) 'Understanding diversity management practices: Implications of institutional theory and resourcebased theory', Group \& Organization Management, 36(1), pp. 6-38.

Zucker, L.G. (1977) 'The role of institutionalization in cultural persistence', American Sociological Review, pp. 726-743. 